\title{
ANALISIS PENGGUNAAN ALAT PELINDUNG DIRI (APD) COVID-19 PADA PETUGAS PUSKESMAS DI KOTA PADANG
}

\author{
Ayulia Fardila Sari ZA ${ }^{1}$, Syafrawati ${ }^{2}$, Laa Tania Fizikriy ${ }^{3}$ \\ Fakultas Kesehatan Masyarakat, Universitas Andalas \\ ayuliafardila@gmail.com ${ }^{1}$, syafrawati@gmail.com²
}

\begin{abstract}
Health workers are groups that are vulnerable to contracting COVID-19. There are 20 health workers in West Sumatra test positive for COVID-19 until April 30 th 2020, while six of them are Padang primary health care officers. Using Personal Protective Equipment (PPE) is important to prevent and reduce COVID-19 transmission risk of health workers. This study aimed to measure factors of using PPE for Padang primary health care officers. Research used a quantitative method with cross sectional design in 12 Padang primary health care from March to July 2020. Independent variables were age, PPE availability, leadership support, knowledge, and attitudes. Dependent variable was PPE usage behavior. Research population was health care officers who directly contacted with people in Padang primary health care area with 100 samples. Primary data collection used questionnaire with accidental sampling technique and analyzed using bivariate analysis. There was a significant relationship between age and PPE usage behavior for health care officers, $p$ value $=0.037(p<0.05)$. There was no significant relationship among PPE availability $(p=0.197)$, leadership support $(p=0.480)$, knowledge $(p=0.936)$, and attitudes ( $p=0.747)$ with PPE usage behavior for primary health care workers. Age factor is related to the use of PPE for Padang public health center officers. Suggested to heads of primary health care to increase workers' motivation using complete PPE.
\end{abstract}

Keywords :Personal Protective Equipments (PPE), COVID-19, Public Health Center Officers

\begin{abstract}
ABSTRAK
Petugas kesehatan adalah salah satu kelompok yang rentan tertular penyakit Coronavirus Disease 2019 (COVID-19). Hingga 30 April 2020 terdapat 20 orang tenaga kesehatan yang positif COVID-19 di Provinsi Sumatera Barat, enam diantaranya adalah petugas puskesmas di Kota Padang. Penggunaan Alat Pelindung Diri (APD) menjadi sangat penting bagi petugas puskesmas untuk mencegah dan mengurangi risiko terpapar COVID-19. Tujuan penelitian ini adalah mengukur faktor yang berhubungan dengan penggunaan APD dalam pencegahan COVID-19 pada petugas puskesmas di Kota Padang. Penelitian ini menggunakan metode kuantitatif dengan desain cross sectional. Dilaksanakan pada bulan Maret - Juli 2020 di 12 Puskesmas Kota Padang. Variabel independen pada penelitian ini adalah pengetahuan, sikap, usia, ketersediaan APD, dan dukungan pimpinan. Sedangkan variabel dependennya adalah perilaku penggunaan APD. Populasi penelitian adalah petugas puskesmas yang kontak langsung dengan pengunjung dan masyarakat di wilayah kerja puskesmas di Kota Padang dengan jumlah sampel 100 orang. Pengumpulan data primer menggunakan kuesioner dengan dengan teknik accidental sampling. Analisis data dilakukan secara bivariat. Hasil penelitian didapatkan bahwa terdapat hubungan yang signifikan antara usia dengan perilaku penggunaan APD pada petugas puskesmas, dengan nilai $\mathrm{p}=0.037 \quad(\mathrm{p}<0.05)$. Tidak terdapat hubungan yang signifikan antara pengetahuan $(\mathrm{p}=0.936)$, sikap $(\mathrm{p}=0.747)$, ketersediaan APD $(\mathrm{p}=0.197)$, dan dukungan pimpinan $(\mathrm{p}=0.480)$ dengan perilaku penggunaan APD pada petugas puskesmas. Faktor usia berhubungan dengan penggunaan APD pada petugas puskesmas di Kota Padang. Disarankan kepada pimpinan puskesmas agar meningkatkan motivasi petugas untuk menggunakan APD lengkap ketika bertugas.
\end{abstract}

Kata Kunci : Alat Pelindung Diri (APD), COVID-19, Petugas Puskesmas

PENDAHULUAN

Coronavirus Disease 2019 (COVID19) merupakan penyakit menular yang disebabkan oleh virus jenis baru (Sars-CoV2) yang belum pernah teridentifikasi sebelumnya pada manusia. Virus ini 
diketahui pertama kali berasal dari Wuhan, Tiongkok. Ditemukan pada akhir Desember tahun 2019 dan hingga 30 April 2020 sudah menjangkiti 213 negara (World Health Organization, 2020). Tanda dan gejala umum infeksi COVID-19 antara lain: gejala gangguan pernapasan akut seperti demam, batuk, dan sesak napas. Masa inkubasi virus rata-rata 5-6 hari dengan masa inkubasi terpanjang 14 hari. Pada kasus COVID-19 yang berat dapat menyebabkan pneumonia, sindrom pernapasan akut, gagal ginjal, hingga kematian (Direktorat Jenderal Pencegahan dan Pengendalian Penyakit, 2020).

Laporan resmi World Health Organization (2020) hingga 30 April 2020 menyatakan bahwa lebih dari 3 juta jiwa terjangkit COVID-19 dengan angka kematian mencapai 217 ribu jiwa. Tanggal 11 Maret 2020 WHO menetapkan COVID19 sebagai pandemi karena tingkat penyebaran yang tinggi terhadap virus ini. Pandemi merupakan wabah penyakit yang menjangkiti banyak negara di dunia. Sedangkan Indonesia menetapkan COVID19 sebagai bencana nasional pada 13 Maret 2020.

Indonesia melaporkan kasus konfirmasi COVID-19 pertama sebanyak 2 kasus pada tanggal 2 Maret 2020. Menurut data gugus tugas percepatan penanganan COVID-19 Indonesia, jumlah kasus hingga tanggal 30 April 2020 adalah sebanyak 10 ribu lebih kasus dengan jumlah kematian 792 jiwa $(7,8 \%)$. Kasus tersebut tersebar di 34 provinsi dan 310 kabupaten/kota. Provinsi dengan jumlah kasus konfirmasi positif terbanyak adalah DKI Jakarta, Jawa Barat. dan Jawa Timur (Gugus Tugas Percepatan Penanganan COVID-19 Indonesia).

Provinsi Sumatera Barat (Sumbar) memiliki kasus konfirmasi positif COVID19 terbanyak di pulau Sumatera dan nomor 10 di tingkat nasional hingga tanggal $5 \mathrm{Mei}$ 2020 (Gugus Tugas Percepatan Penanganan COVID-19 Indonesia, 2020). Sumbar melaporkan kasus konfirmasi COVID-19 pertama sebanyak 5 kasus pada 26 Maret
2020. Menurut data Dinas Kesehatan Provinsi Sumbar, sampai tanggal 30 April 2020 jumlah kasus mencapai 148 jiwa dengan kematian 15 orang. Kota Padang merupakan kota dengan kasus positif terbanyak yaitu 99 orang yang tersebar di hampir seluruh kecamatan di Kota Padang. (Dinas Kesehatan Kota Padang, 2020).

COVID-19 dapat menular dari manusia ke manusia melalui percikan batuk/bersin (droplet). Orang yang paling berisiko tertular penyakit ini adalah orang yang kontak erat dengan pasien COVID-19 termasuk yang merawat pasien dalam hal ini tenaga kesehatan. Tenaga kesehatan mempunyai risiko tinggi terhadap kemungkinan terpapar. Hal ini dibuktikan dengan telah banyaknya petugas kesehatan yang dinyatakan positif COVID-19 (Direktorat Jenderal Pencegahan dan Pengendalian Penyakit, 2020). Data dari Komisi Kesehatan Nasional China melaporkan bahwa ada setidaknya 1.716 kasus tenaga medis tertular COVID-19 dengan $80 \%$ diantaranya mengalami gejala ringan (Direktorat Jenderal Pencegahan dan Pengendalian Penyakit, 2020). Sementara itu, terdapat 174 orang tenaga kesehatan di Indonesia yang positif terpapar COVID-19 hingga tanggal 11 April 2020. Juru bicara Ikatan Dokter Indonesia (IDI) menyatakan ada sekitar 47 tenaga kesehatan yang meninggal akibat COVID-19 di Indonesia (BBC News Indonesia, 2020). Berdasarkan analisis jejaring riwayat kontak pasien positif di Provinsi Sumatera Barat didapatkan bahwa $19,83 \%$ pasien memiliki kontak dengan tenaga kesehatan (Djafri, Putri, \& Pradipta, 2020). Hingga tanggal 30 April 2020 terdapat sekitar 20 orang tenaga kesehatan yang positif COVID-19 di Provinsi Sumatera Barat, enam diantaranya adalah petugas puskesmas di Kota Padang (Covesia News, 2020).

Upaya untuk mencegah petugas kesehatan terinfeksi COVID-19 adalah dengan mematuhi praktik pencegahan dan pengendalian infeksi. Upaya ini meliputi pengendalian administratif, lingkungan, 
teknik/engineering dan penggunaan Alat Pelindung Diri (APD) yang tepat. APD bertindak sebagai penghalang antara bahan infeksius (misalnya virus dan bakteri) dengan kulit, mulut, hidung, atau mata (selaput lendir) tenaga kesehatan dan pasien (Direktorat Jenderal Pelayanan Kesehatan RI, 2020). APD membantu memastikan bahwa seseorang aman dari bahaya fisik yang mungkin dihadapi di lingkungan kerja. Penggunaan APD dibutuhkan untuk membantu memberikan pelayanan kesehatan dengan aman (John L. Hick \& Craig D. Thorne, 2009).

Ada beberapa faktor yang mempengaruhi tenaga kesehatan dalam menggunakan APD saat bertugas. Berdasarkan penelitian yang dilakukan Zaki, M dkk (2018) faktor-faktor yang mempengaruhi perawat dalam menggunakan APD saat bertugas adalah pengetahuan, sikap, ketersediaan APD, dukungan rekan kerja, serta pengawasan. Berdasarkan penelitian yang dilakukan Apriluana, Khairiyati, \& Setyaningrum, (2016), menyatakan bahwa terdapat hubungan yang signifikan antara usia dengan penggunaan APD oleh tenaga kesehatan di RSUD Banjar. Menurut penelitian Sanjaya (2018), diketahui bahwa ada hubungan yang signifikan antara sikap dan perilaku penggunaan APD pada petugas puskesmas di Kabupaten Sleman. Selain itu, hasil penelitian Atmanto (2011). bahwa sebagian besar pekerja menyatakan akan bekerja tanpa menggunakan APD jika tidak adanya dukungan atau perhatian dari pimpinan.

Berdasarkan studi pendahuluan terhadap petugas puskesmas di Kota Padang didapatkan ketidakkonsistenan petugas dalam memakai APD. Dua dari sepuluh petugas kadang-kadang memakai APD saat bertugas. Penggunaan APD sangatlah penting bagi petugas puskesmas untuk mencegah dan mengurangi risiko terpapar COVID-19 dari masyarakat, baik yang sudah terkonfirmasi maupun yang belum. Tujuan penelitian ini adalah menganalisis faktor-faktor yang berhubungan dengan penggunaan Alat Pelindung Diri (APD) dalam pencegahan COVID-19 pada petugas puskesmas di Kota Padang tahun 2020

\section{METODE}

Penelitian ini adalah penelitian kuantitatif dengan desain cross sectional. Variabel independen pada penelitian ini adalah: usia, pengetahuan, sikap, ketersediaan APD, dan dukungan pimpinan. Sementara itu variabel dependennya adalah perilaku penggunaan APD dalam pencegahan COVID-19 pada petugas puskesmas di Kota Padang.

Penelitian ini dilaksanakan pada bulan Maret-Juli 2020 di 12 Puskesmas yang ada di Kota Padang. Pemilihan puskesmas dilakukan secara acak. Populasi pada penelitian ini adalah petugas puskesmas yang kontak langsung dengan pengunjung dan masyarakat di wilayah kerja puskesmas, yaitu dokter, dokter gigi, bidan, perawat, dan petugas surveilans dengan total berjumlah 850 orang. Besar sampel pada penelitian ini didapat dengan menggunakan Teori Slovin dan ditambah dengan dropout $10 \%$, maka didapat jumlah sampel sebanyak 100 petugas. Kriteria inklusi nya adalah petugas yang bersedia mengisi kuesioner dan tidak sedang dalam masa cuti semenjak kasus pertama COVID-19 di Kota Padang. Sedangkan kriteria ekslusinya adalah petugas yang tidak bersedia menjadi responden.

Data sekunder diperoleh dari Dinas Kesehatan Provinsi Sumatera Barat dan telaah dokumen seperti buku, literatur, profil, laporan, dan data-data yang menjadi sumber dalam penelitian. Sedangkan data primer berupa kuesioner mengenai faktor yang mempengaruhi penggunaan APD. Kuesioner yang digunakan merupakan kuesioner yang diadopsi dari penelitian Ningsih, $H$ dan Madyanti, DR dengan sedikit perubahan (Madyanti, 2012; Ningsih, 2018). Kuesioner tersebut dilakukan uji validitas dan reliabilitas 
sebelum digunakan. Analisis data pada penelitian ini adalah menggunakan analisis bivariat.

\section{HASIL}

\section{Karakteristik Responden}

Karakteristik responden dalam penelitian ini dapat dilihat pada tabel berikut:

Tabel 1 Distribusi Frekuensi Karakteristik Responden

\begin{tabular}{|c|c|c|}
\hline $\begin{array}{c}\text { Karakteristik } \\
\text { Responden }\end{array}$ & $\begin{array}{l}\text { Frekuensi } \\
\text { (n) }\end{array}$ & $\begin{array}{c}\text { Persentase } \\
(\%)\end{array}$ \\
\hline \multicolumn{3}{|l|}{ Jenis Kelamin } \\
\hline Laki-laki & 10 & 10.0 \\
\hline Perempuan & 90 & 90.0 \\
\hline \multicolumn{3}{|l|}{$\begin{array}{l}\text { Pendidikan } \\
\text { terakhir }\end{array}$} \\
\hline D-III & 53 & 53.0 \\
\hline S-1 & 44 & 44.0 \\
\hline Lain-lain & 3 & 3.0 \\
\hline \multicolumn{3}{|l|}{ Profesi } \\
\hline Dokter & 25 & 25.0 \\
\hline Dokter gigi & 7 & 7.0 \\
\hline Bidan & 29 & 29.0 \\
\hline Perawat & 25 & 25.0 \\
\hline Lain-lain & 14 & 14.0 \\
\hline \multicolumn{3}{|l|}{$\begin{array}{l}\text { Mulai } \\
\text { Menggunakan } \\
\text { APD COVID-19 }\end{array}$} \\
\hline \begin{tabular}{lr}
\multicolumn{2}{l}{ Pengumuman } \\
kasus & positif \\
pertama & di \\
Indonesia & \\
\end{tabular} & 33 & 33.0 \\
\hline $\begin{array}{l}\text { Pengumuman } \\
\text { kasus positif } \\
\text { pertama di Kota } \\
\text { Padang }\end{array}$ & 58 & 58.0 \\
\hline $\begin{array}{l}\text { Pemberlakuan } \\
\text { PSBB di Kota } \\
\text { Padang }\end{array}$ & 4 & 4.0 \\
\hline Lain-lain & 5 & 5.0 \\
\hline Total & 100 & 100.0 \\
\hline
\end{tabular}

Berdasarkan tabel 1 terlihat bahwa jumlah responden pada penelitian ini adalah
100 orang. Hampir seluruh responden adalah perempuan dengan persentase $90 \%$. Untuk kelompok pendidikan terakhir, responden paling banyak berlatar belakang pendidikan Diploma III (D-III) sebesar $53 \%$. Responden paling banyak berprofesi sebagai bidan yaitu sebesar $29 \%$. Frekuensi responden mulai menggunakan APD COVID-19 tertinggi (58\%) dimulai semenjak pengumuman kasus positif pertama di Kota Padang (26 Maret 2020).

Frekuensi penggunaan APD pada petugas puskesmas adalah seperti dalam tabel berikut:

Tabel 2 Frekuensi Penggunaan Alat Pelindung Diri (APD)

\begin{tabular}{llll}
\hline $\begin{array}{l}\text { Alat } \\
\text { Pelindung } \\
\text { Diri (APD) }\end{array}$ & $\begin{array}{l}\text { Ya } \\
(\boldsymbol{\%})\end{array}$ & $\begin{array}{l}\text { Tidak } \\
(\boldsymbol{\%})\end{array}$ & $\begin{array}{l}\text { Kadang- } \\
\text { Kadang } \\
(\%)\end{array}$ \\
\hline $\begin{array}{l}\text { Masker } \\
\text { bedah }\end{array}$ & 99.0 & 0.0 & 1.0 \\
\hline $\begin{array}{l}\text { Sarung } \\
\text { tangan }\end{array}$ & 94.0 & 2.0 & 4.0 \\
\hline $\begin{array}{l}\text { Gaun } \\
\text { Penutup } \\
\text { kepala }\end{array}$ & 88.0 & 2.0 & 10.0 \\
\hline $\begin{array}{l}\text { Pelindung } \\
\text { mata }\end{array}$ & $\mathbf{5 1 . 0}$ & $\mathbf{2 8 . 0}$ & $\mathbf{2 1 . 0}$ \\
\hline $\begin{array}{l}\text { Pelindung } \\
\text { wajah }\end{array}$ & 86.0 & 2.0 & 12.0 \\
\hline $\begin{array}{l}\text { Sepatu } \\
\text { pelindung }\end{array}$ & $\mathbf{2 0 . 0}$ & $\mathbf{4 9 . 0}$ & $\mathbf{3 1 . 0}$ \\
\hline
\end{tabular}

Tabel 2 menunjukkan 99\% responden sudah menggunakan masker medis, $88 \%$ sudah menggunakan gaun. Sementara itu $49 \%$ responden tidak menggunakan sepatu pelindung .

\section{Uji Normalitas Data}

Variabel yang diuji adalah variabel perilaku, usia, pengetahuan, sikap, ketersediaan APD, dan dukungan pimpinan puskesmas. Berikut adalah tabel rangkuman uji normalitas menggunakan uji Kolmogorov Smirnov. 
Tabel 3 Hasil Uji Normalitas

\begin{tabular}{ll}
\hline Variabel & $\boldsymbol{P}$-Value \\
\hline Usia & 0.662 \\
\hline Pengetahuan & 0.348 \\
\hline Sikap & 0.424 \\
\hline Ketersediaan APD & 0.078 \\
\hline Dukungan Pimpinan & 0.066 \\
\hline
\end{tabular}

Berdasarkan tabel 3 diketahui bahwa semua variabel memiliki nilai $\mathrm{p}>0.05$. Hal ini berarti semua variabel diatas berdistribusi normal.

Hubungan Usia dengan Perilaku Penggunaan APD pada Petugas Puskesmas

Tabel 4 Uji Silang Usia Responden dengan Perilaku Penggunaan APD pada Petugas Puskesmas di Kota Padang

\begin{tabular}{|c|c|c|c|c|c|c|c|c|}
\hline \multirow{3}{*}{ Usia } & \multicolumn{4}{|c|}{ Perilaku Penggunaan APD } & \multirow{2}{*}{\multicolumn{2}{|c|}{ Total }} & \multirow{3}{*}{ PR 95\% CI } & \multirow{3}{*}{ p-value } \\
\hline & \multicolumn{2}{|c|}{ Tidak Lengkap } & \multicolumn{2}{|c|}{ Lengkap } & & & & \\
\hline & $\mathbf{n}$ & $\%$ & $\mathbf{n}$ & $\%$ & $\mathbf{n}$ & $\%$ & & \\
\hline Muda & 18 & 41.9 & 25 & 58.1 & 43 & 100 & \multirow{3}{*}{$\begin{array}{l}0.389 \\
(0.172-0.879)\end{array}$} & \multirow{3}{*}{0.037} \\
\hline Tua & 37 & 64.9 & 20 & 35.1 & 57 & 100 & & \\
\hline Total & 55 & 55.0 & 45 & 45.0 & 100 & 100 & & \\
\hline
\end{tabular}

Tabel 4 menunjukkan bahwa responden dengan perilaku penggunaan APD tidak lengkap lebih banyak pada responden yang memiliki usia tua $(64.9 \%)$ daripada yang memiliki usia muda (41.9\%). Hasil uji statistik menunjukkan nilai $\mathrm{p}=0.037(\mathrm{p}<0.05)$, artinya $\mathrm{H}_{\mathrm{a}}$ diterima dan
$\mathrm{H}_{0}$ ditolak. Hal ini berarti terdapat hubungan yang signifikan antara usia dengan perilaku penggunaan APD. Hasil analisis juga menunjukkan nilai $\mathrm{PR}=0.389$ yang artinya responden yang memiliki usia muda memiliki peluang 0.3 kali untuk menggunakan APD secara tidak lengkap.

\section{Hubungan Pengetahuan dengan Perilaku Penggunaan APD pada Petugas Puskesmas}

Tabel 5 Uji Silang Pengetahuan Responden dengan Perilaku Penggunaan APD pada Petugas Puskesmas

\begin{tabular}{|c|c|c|c|c|c|c|c|c|}
\hline \multirow{3}{*}{ Pengetahuan } & \multicolumn{4}{|c|}{ Perilaku Penggunaan APD } & \multirow{2}{*}{\multicolumn{2}{|c|}{ Total }} & \multirow{3}{*}{ PR 95\% CI } & \multirow{3}{*}{$p$-value } \\
\hline & \multicolumn{2}{|c|}{ Tidak Lengkap } & \multicolumn{2}{|c|}{ Lengkap } & & & & \\
\hline & (n) & $\%$ & (n) & $\%$ & (n) & $\%$ & & \\
\hline Rendah & 29 & 53.7 & 25 & 46.3 & 54 & 100 & \multirow{3}{*}{$\begin{array}{l}0.892 \\
(0.404-1.968)\end{array}$} & \multirow{3}{*}{0.936} \\
\hline Tinggi & 26 & 56.5 & 20 & 43.5 & 46 & 100 & & \\
\hline Total & 55 & 55.0 & 45 & 45.0 & 100 & 100 & & \\
\hline
\end{tabular}

Tabel 5 menunjukkan bahwa responden dengan penggunaan APD tidak lengkap lebih banyak pada responden dengan pengetahuan rendah $(53.7 \%)$ dari pada responden yang memiliki pengetahuan tinggi (56.5\%). Hasil uji statistik menunjukkan nilai $\mathrm{p}=0.936(\mathrm{p}>0.05)$ yang artinya tidak ada hubungan yang signifikan antara pengetahuan dengan perilaku penggunaan APD pada petugas puskesmas di Kota Padang tahun 2020. 
Hubungan Sikap dengan Perilaku Penggunaan APD Pada Petugas Puskesmas

Tabel 6 Uji Silang Sikap dengan Perilaku Penggunaan APD pada Petugas Puskesmas

\begin{tabular}{lllllllll}
\hline \multirow{2}{*}{ Sikap } & \multicolumn{3}{l}{ Perilaku Penggunaan APD } & \multirow{2}{*}{ Total } & \multirow{2}{*}{ PR 95\% CI } & p-value \\
\cline { 2 - 6 } & \multicolumn{2}{l}{ Tidak Lengkap } & \multicolumn{2}{c}{ Lengkap } & & & & \\
\cline { 2 - 6 } & $\mathbf{n}$ & $\mathbf{\%}$ & $\mathbf{n}$ & $\mathbf{\%}$ & $\mathbf{n}$ & $\mathbf{\%}$ & & \\
\hline Negatif & 31 & 57.4 & 23 & $42, .6$ & 54 & 100 & 1.236 & 0.747 \\
Positif & 24 & 52.2 & 22 & 46.8 & 46 & 100 & $(0.560-2.725)$ & \\
Total & 55 & 55.0 & 45 & 45.0 & 100 & 100 & & \\
\hline
\end{tabular}

Tabel 6 menunjukkan bahwa responden yang menggunakan APD tidak lengkap lebih banyak pada responden yang memiliki sikap negatif $(57 \%)$ dari pada responden dengan sikap positif $(52,2 \%)$. Hasil uji statistik menunjukkan nilai $\mathrm{p}=0.747 \quad(\mathrm{p}>0.05) \quad$ yang artinya tidak terdapat hubungan yang signifikan antara sikap dengan perilaku penggunaan APD pada petugas puskesmas di Kota Padang tahun 2020.

Hubungan Ketersediaan APD dengan Penggunaan APD pada Petugas Puskesmas

Tabel 7 Uji Silang Ketersediaan Perilaku Penggunaan APD pada Petugas Puskesmas

\begin{tabular}{|c|c|c|c|c|c|c|c|c|}
\hline \multirow{3}{*}{$\begin{array}{l}\text { Ketersediaan } \\
\text { APD }\end{array}$} & \multicolumn{4}{|c|}{ Perilaku Penggunaan APD } & \multirow{2}{*}{\multicolumn{2}{|c|}{ Total }} & \multirow{3}{*}{ PR $95 \%$ CI } & \multirow{3}{*}{ p-value } \\
\hline & \multicolumn{2}{|c|}{ Tidak Lengkap } & \multicolumn{2}{|c|}{ Lengkap } & & & & \\
\hline & $\mathbf{n}$ & $\%$ & $\mathbf{n}$ & $\%$ & n & $\%$ & & \\
\hline Tidak cukup & 29 & 63.0 & 17 & 37.0 & 56 & 100 & \multirow{3}{*}{$\begin{array}{l}1.837 \\
(0.824-4.097)\end{array}$} & \multirow{3}{*}{0.197} \\
\hline Cukup & 26 & 48.1 & 28 & 51.9 & 54 & 100 & & \\
\hline Total & 55 & 55.0 & 45 & 45.0 & 100 & 100 & & \\
\hline
\end{tabular}

Tabel 7 menunjukkan bahwa responden yang menggunakan APD tidak lengkap lebih banyak pada responden yang memiliki ketersediaan APD tidak mencukupi di puskesmasnya (63\%) dari pada responden yang memiliki APD yang cukup di puskesmasnya (48.1\%). Hasil uji statistik menunjukkan nilai $\mathrm{P}=0.197$ ( $>0.05$ ) artinya bahwa tidak terdapat hubungan yang signifikan antara ketersediaan APD di puskesmas dengan penggunaan APD pada petugas puskesmas di Kota Padang tahun 2020.

Hubungan Dukungan Pimpinan dengan Perilaku Penggunaan APD pada Petugas Puskesmas

Tabel 8 Uji Silang Dukungan Pimpinan dengan Penggunaan APD pada Petugas Puskesmas

\begin{tabular}{|c|c|c|c|c|c|c|c|c|}
\hline \multirow{3}{*}{$\begin{array}{l}\text { Dukungan } \\
\text { Pimpinan }\end{array}$} & \multicolumn{4}{|c|}{ Perilaku Penggunaan APD } & \multirow{2}{*}{\multicolumn{2}{|c|}{ Total }} & \multirow{3}{*}{ PR 95\% CI } & \multirow{3}{*}{$p$-value } \\
\hline & \multicolumn{2}{|c|}{ Tidak Lengkap } & \multicolumn{2}{|c|}{ Lengkap } & & & & \\
\hline & (n) & $\%$ & (n) & $\%$ & (n) & $\%$ & & \\
\hline Tidak Ada & 27 & 60.0 & 18 & 40.0 & 45 & 100.0 & \multirow{3}{*}{$\begin{array}{c}1.446 \\
(0.652-3.209)\end{array}$} & \multirow{3}{*}{0.480} \\
\hline Ada & 28 & 50.9 & 27 & 49.1 & 55 & 100.0 & & \\
\hline Total & 55 & 55.0 & 45 & 45.0 & 100 & 100.0 & & \\
\hline
\end{tabular}


Tabel 8 menunjukkan bahwa responden yang menggunakan APD tidak lengkap lebih banyak pada responden yang mendapat dukungan dari pimpinan puskesmas $(50.9 \%)$ dari pada responden yang tidak mendapat dukungan dari pimpinan (60\%). Hasil uji statistik

\section{PEMBAHASAN}

\section{Hubungan Usia dengan Perilaku Penggunaan APD pada Petugas Puskesmas di Kota Padang}

Hasil penelitian pada petugas puskesmas di Kota Padang diketahui responden dengan perilaku penggunaan APD tidak lengkap lebih banyak pada responden dengan usia tua $(64.9 \%)$. Hasil uji statistik menunjukkan adanya hubungan yang signifikan antara usia dengan perilaku penggunaan APD pada petugas puskesmas di Kota Padang tahun 2020. Hasil penelitian juga menunjukkan bahwa petugas berusia muda berpeluang $0.389 \mathrm{kali}$ untuk menggunakan APD secara tidak lengkap .

Hasil penelitian ini sejalan dengan penelitian Supiana (2013) tentang penggunaan APD pada bidan di RS KIA Sadewa Yogyakarta. Hasil penelitian tersebut menunjukkan bahwa adanya hubungan yang signifikan antara usia dengan perilaku penggunaan APD dengan nilai $\mathrm{p}=0,000(\mathrm{p}<0.05)$. Penelitian ini juga sejalan dengan penelitian Apriluana G, et al. (2016) tentang hubungan antara usia, jenis kelamin, lama kerja, pengetahuan, sikap dan ketersediaan APD dengan perilaku penggunaan APD pada tenaga kesehatan. Hasil penelitian tersebut menunjukkan adanya hubungan yang signifikan antara usia dengan penggunaan APD dengan nilai $\mathrm{p}=0.006(\mathrm{p}<0.05)$.

Usia merupakan umur individu yang terhitung mulai saat dilahirkan sampai beberapa tahun (Nursalam, 2008). Usia adalah lamanya waktu hidup seseorang dalam tahun yang dihitung sejak dilahirkan sampai berulang tahun yang terakhir menunjukkan nilai $\mathrm{p}=0.480 \quad(\mathrm{p}>0.05)$ artinya tidak terdapat hubungan yang signifikan antara dukungan pimpinan dengan perilaku penggunaan APD pada petugas puskesmas di Kota Padang tahun 2020 .

(Notoatmodjo, 2003). Usia merupakan salah satu hal yang mempengaruhi pengetahuan. Semakin tua usia seseorang maka proses-proses perkembangan mentalnya bertambah baik, akan tetapi pada usia tertentu, bertambahnya proses perkembangan mental ini tidak secepat ketika berusia belasan tahun (Hanifah, 2010).

Semakin bertambah usia, maka akan semakin banyak pengalaman yang dimiliki dan semakin banyak informasi yang didapatkan serta semakin memahami upaya pencegahan dari terjadinya bahaya yang ditimbulkan karena tidak menggunakan APD. Menurut Pangihutan, (2019), umur dapat menjadi penentu terhadap kepatuhan penggunaan APD. Semakin tinggi umur petugas maka akan lebih mengikuti standar penggunaan APD

\section{Hubungan Pengetahuan dengan Perilaku Penggunaan APD pada Petugas Puskesmas di Kota Padang}

Hasil penelitian diketahui responden dengan perilaku penggunaan APD tidak lengkap lebih banyak pada responden yang memliki pengetahuan rendah $(53,7 \%)$ dari pada yang memiliki pengetahuan tinggi (56,5\%). Hasil uji statistik menunjukkan nilai $\mathrm{p}=0,936(\mathrm{p}>0,05)$ yang artinya tidak terdapat hubungan yang signifikan antara tingkat pengetahuan dengan perilaku penggunaan APD COVID-19 pada petugas puskesmas di Kota Padang tahun 2020.

Hasil penelitian ini sejalan dengan penelitian Amaludin \& Indragini (2017) yang menyatakan bahwa tidak terdapat hubungan yang signifikan antara pengetahuan dengan perilaku penggunaan APD pada pekerja bagian jaring di PT Artia 
Daya Mulia Cirebon Begitu juga dengan penelitian Rachman et al. (2020) bahwa tidak terdapat hubungan yang signifikan antara pengetahuan dengan perilaku penggunaan APD pada pekerja di PT Sarandi Karya Nugraha Sukabumi.

Hasil penelitian diketahui bahwa tidak ada hubungan yang signifikan antara pengetahuan dengan perilaku penggunaan APD. Hal ini dikarenakan bukan hanya pengetahuan yang mempengaruhi perilaku penggunaan APD, tetapi banyak faktor lain seperti pengaruh teman sejawat, adanya kebijakan yang mengatur penggunaan APD, dan lain-lain. Hal ini sesuai dengan teori Lawrence Green (1980) dalam Notoatmodjo (2010), bahwa perilaku kesehatan ditentukan oleh 3 faktor utama, yakni faktor pendorong (pengetahuan, sikap, keyakinan, kepercayaan, nilai, tradisi, dll), faktor pemungkin (saranaprasarana yang mendukung seperti ketersediaan barang), dan faktor pendorong yang mendorong atau memperkuat perilaku.

Menurut $\mathrm{Hu}$ et al., (2012) perilaku dapat berubah tanpa pengaruh dari pengetahuan, namun untuk perubahan perilaku dengan tingkat kepatuhan penggunaan APD yang tinggi akan lebih berkelanjutan jika diiringi dengan pengetahuan yang tinggi. Dilihat dari hasil penelitian bahwa responden yang tidak menggunakan APD lengkap lebih banyak pada responden dengan pengetahuan rendah tentang APD COVID-19. Sehingga perlu diadakan pelatihan untuk meningkatkan pengetahuan petugas mengenai alat pelindung disertai fungsi dan manfaat dari pemakaian APD dengan lengkap.

\section{Hubungan Sikap dengan Perilaku Penggunaan APD pada Petugas Puskesmas Kota di Kota Padang}

Hasil penelitian diketahui bahwa responden yang menggunakan APD tidak lengkap lebih banyak pada responden yang memiliki sikap negatif $(57 \%)$ dari pada responden dengan sikap positif $(52,2 \%)$. Hasil uji statistik menunjukkan nilai $\mathrm{p}=0,747 \quad(\mathrm{p}>0,05) \quad$ yang artinya tidak terdapat hubungan yang signifikan antara sikap dengan perilaku penggunaan APD COVID-19 pada petugas puskesmas di Kota Padang tahun 2020.

Hasil penelitian ini sejalan dengan penelitian Madyanti (2012) tentang faktorfaktor yang mempengaruhi penggunaan APD pada bidan saat melakukan pertolongan persalinan di RSUD Bengkalis tahun 2012. Hasil penelitian tersebut menunjukkan tidak adanya hubungan yang signifikan antara sikap dengan perilaku penggunaan APD dengan nilai $\mathrm{p}=0.257$ ( $>0.05)$. Sikap merupakan reaksi atau respon yang masih tertutup dari seseorang terhadap suatu stimulus atau objek. Keadaan mental dan kesiapan yang diatur melalui pengalaman, memberikan pengaruh dinamik atau terarah terhadap respon individu pada semua objek yang berkaitan dengannya. Sikap secara nyata menunjukkan konotasi adanya kesesuaian reaksi terhadap stimulus tertentu (Notoatmodjo, 2011).

Hasil penelitian ini didapatkan bahwa tidak terdapat hubungan yang signifikan antara sikap dengan perilaku penggunaan APD pada petugas puskesmas. Hal ini dikarenakan bukan hanya sikap yang menjadi faktor terbentuknya perilaku petugas puskesmas, akan tetapi ada faktor lain yang mendorong petugas untuk menggunakan APD. Lingkungan kerja petugas juga mempengaruhi perilaku penggunaan APD, seperti ada atau tidaknya rambu-rambu Kesehatan dan Keselamatan Kerja (K3) dan standar prosedur penggunaan APD yang harus terpajang di beberapa titik unit puskesmas. Kenyamanan petugas dalam menggunakan APD COVID-19 menjadi salah satu faktor yang mendukung terwujudnya perilaku penggunaan APD. 


\section{Hubungan Ketersediaan APD di Puskesmas dengan Perilaku Penggunaan APD pada Petugas Puskesmas di Kota Padang}

Hasil penelitian diketahui bahwa responden yang menggunakan APD tidak lengkap lebih banyak pada responden yang tidak memiliki ketersediaan APD yang mencukupi di puskesmasnya $(63 \%)$ dari pada responden yang memiliki ketersediaan APD yang cukup di puskesmasnya (48.1\%). Hasil uji statistik menunjukkan bahwa nilai $\mathrm{p}=0.197$ yang artinya tidak terdapat hubungan yang signifikan antara ketersediaan APD di puskesmas dengan perilaku penggunaan APD pada petugas puskesmas di Kota Padang tahun 2020.

Penelitian ini sejalan dengan penelitian Apriluana, et al. (2016) tentang hubungan antara usia, jenis kelamin, lama kerja, pengetahuan, sikap dan ketersediaan APD dengan perilaku penggunaan APD pada tenaga kesehatan tahun 2016. Hasil penelitian tersebut menunjukkan tidak terdapat hubungan yang bermakna antara ketersediaan APD dengan perilaku penggunaan APD dengan nilai $\mathrm{p}=0.589$ $(\mathrm{p}>0.05)$

Hasil penelitian didapatkan bahwa tidak terdapat hubungan yang signifikan antara ketersediaan APD di puskesmas dengan perilaku penggunaan APD pada petugas puskesmas. Hal ini dikarenakan terdapat faktor lain yang mempengaruhi perilaku penggunaan APD petugas puskesmas seperti adanya kebijakan dan sanksi bagi penggunaan APD. Berdasarkan hasil penelitian didapatkan bahwa petugas yang tidak menggunakan APD dengan lengkap adalah petugas yang tidak memiliki ketersediaan APD mencukupi di puskesmasnya. Menurut Direktorat Jenderal Pelayanan Kesehatan RI, (2020), COVID-19 merupakan penyakit baru sehingga kebutuhan APD sangat tinggi sementara produksi APD masih terbatas.
Hasil penelitian menyatakan bahwa terdapat beberapa APD yang hanya digunakan untuk kegiatan tertentu seperti turun lapangan. Hal ini dikarenakan keterbatasan ketersediaan APD tersebut. Oleh karena itu sebaiknya pihak manajemen puskesmas mencukupi ketersediaan APD di puskesmas agar petugas merasa aman saat melayani pasien dan terhindar dari bahaya tertular penyakit seperti COVID-19.

\section{Hubungan Dukungan Pimpinan Puskesmas dengan Perilaku Penggunaan APD pada Petugas Puskesmas di Kota Padang}

Hasil penelitian diketahui bahwa responden yang menggunakan APD tidak lengkap lebih banyak pada responden yang mendapat dukungan dari pimpinan puskesmas $(50.9 \%)$ dari pada responden yang tidak mendapat dukungan dari pimpinan puskesmas $(60.0 \%)$. Hasil uji statistik menunjukkan nilai $\mathrm{p}=0.480$ ( $>0.05$ ) yang artinya tidak terdapat hubungan yang signifikan antara dukungan pimpinan dengan perilaku penggunaan APD pada petugas puskesmas di Kota Padang tahun 2020.

Penelitian ini sejalan dengan penelitian Dewantara BS (2016) tentang hubungan motivasi kerja dengan kepatuhan penggunaan APD pada perawat di Jember. Hasil penelitian tersebut menunjukkan tidak terdapat hubungan yang signifikan antara motivasi kerja dengan kepatuhan menggunakan APD pada perawat di Rumah Sakit Paru Jember.

Dukungan yang dapat diberikan pimpinan puskesmas dapat berupa memberikan pujian, mengawasi petugas saat bekerja, atau memberikan sanksi bagi petugas yang tdak menggunakan APD lengkap saat menangani pasien. Menurut Zaki, Ferusgel, \& Siregar (2018), orang tidak menggunakan APD dikarenakan kurang pengetahuan, keterampilan, 
kurangnya pelatihan prosedur atau peraturan mengenai keselamatan kerja Hal ini menunjukkan perlunya pengaruh pimpinan dalam mendukung petugas menggunakan APD dengan lengkap.

Hasil penelitian didapatkan bahwa tidak terdapat hubungan yang signifikan antara dukungan pimpinan dengan perilaku penggunaan APD pada petugas puskesmas. Hal ini dikarenakan banyaknya faktor yang membentuk perilaku seseorang. Perilaku merupakan hasil daripada segala macam pengalaman serta interaksi manusia dengan lingkungannya yang terwujud dalam bentuk pengetahuan, sikap dan tindakan. Perilaku merupakan respon seorang individu terhadap stimulus yang berasal dari dalam maupun luar dirinya. Menurut Notoatmodjo (2011), faktor yang mempengaruhi perilaku adalah faktor genetik seperti (ras, jenis kelamin, sifat fisik, sifat kepribadian, dan lain-lain) serta faktor eksogen seperti lingkungan (sosial ekonomi, pekerjaan, kebudayaan).

Oleh sebab itu, pimpinan diharapkan dapat menekankan pentingnya penggunaan APD bagi petugas puskesmas dengan melakukan simulasi / pelatihan dan memberikan imbalan tambahan bagi petugas yang selalu menggunakan APD lengkap dalam melaksanakan pelayanan kepada pasien.

\section{KESIMPULAN}

Terdapat hubungan yang signifikan antara usia dengan perilaku penggunaan APD COVID-19. Tidak terdapat hubungan yang signifikan antara pengetahuan, sikap, dan dukungan pimpinan dengan perilaku penggunaan APD. Disarankan kepada pimpinan puskesmas agar melakukan workshop untuk meningkatkan pengetahuan dan motivasi petugas dalam menggunakan APD lengkap ketika bekerja. Untuk penelitian selanjutnya disarankan melakukan penelitian dengan metode sampling yang berbeda dan menggunakan desain kualitatif untuk analisis mendalam.

\section{UCAPAN TERIMAKASIH}

Terima kasih kepada FKM Unand yang sudah mendanai penelitian ini, serta kepada responden yang telah bekerja sama dengan baik.

\section{DAFTAR PUSTAKA}

Amaludin, E. N., \& Indragini, S. (2017). Hubungan Pengetahuan dan Sikap dengan Penggunaan Alat Pelindung Diri (APD) pada Tenaga Kerja Bagian Jaring. Jurnal Kesehatan Stikes Cirebon, 8(1).

Apriluana, G., Khairiyati, 1., \& Setyaningrum, R. (2016). Hubungan antara Usia, Jenis Kelamin, Lama Kerja, Pengetahuan, Sikap dan Ketersediaan Alat Pelindung Diri (Apd) dengan Perilaku Penggunaan APD pada Tenaga Kesehatan.

Atmanto, I. S. (2011). Behavioral Determinants Workers In The Use Of Ppe Based On Hazard Assessment In Foundry Company Ceper Klaten.

BBC News Indonesia. Virus corona: Mengapa tenaga kesehatan terus tertular COVID-19 di tengah komitmen pemerintah menyalurkan APD? , from https://www.bbc.com/indonesia/ind onesia-52434794

Covesia News. Enam Pegawai Puskesmas di Kota Padang Positif COVID-19, from

https://www.covesia.com/news/bac a/94812/enam-pegawai-

puskesmas-di-kota-padang-positifCOVID-19

Dinas Kesehatan Kota Padang. Situasi Terkini Perkembangan Kasus Coronavirus Disease COVID-19 Di Kota Padang, from https://dinkes.padang.go.id/

Direktorat Jenderal Pelayanan Kesehatan RI. (2020). Petunjuk Teknis Alat Pelindung Diri (APD) dalam 
Menghadapi Wabah COVID-19. Jakarta: Kementerian Kesehatan RI.

Direktorat Jenderal Pencegahan dan Pengendalian Penyakit. (2020). Pedoman Pencegahan dan Pengendalian Coronavirus Disease (COVID-19). Jakarta: Kementerian Kesehatan RI, Direktorat Jenderal Pencegahan dan Pengendalian Penyakit (P2P).

Djafri, D., Putri, A. S. E., \& Pradipta, Y. (2020). Analisis Jejaring Kontak Pasien Konfirmasi Positif COVID19 di Provinsi Sumatera Barat.

Gugus Tugas Percepatan Penanganan COVID-19 Indonesia. from https://covid19.go.id/

Hanifah, M. (2010). Hubungan Usia dan Tingkat Pendidikan dengan Pengetahuan Wanita Usia 20-50 tahun tentang SADARI.

Hu, X., Zhang, Z., Li, N., Liu, D., Zhang, L., He, W., . . Du, B. (2012). SelfReported Use of Personal Protective Equipment among Chinese Critical Care Clinicians during 2009 H1N1 Influenza Pandemic. PLOS ONE, 7(9).

John L. Hick, \& Craig D. Thorne. (2009). Personal Protective Equipment.

Madyanti, D. R. (2012). Faktor-Faktor yang Mempengaruhi Penggunaan Alat Pelindung Diri (APD) pada Bidan Saat Melakukan Pertolongan Persalinan di RSUD Bengkalis Tahun 2012. Universitas Indonesia.

Ningsih, H. (2018). Faktor yang Berhubungan dengan Penggunaan Alat Pelindung Diri pada Perawat di Instalasi Rawat Inap RSUD Kabupaten Mamuju Sulawesi Barat Tahun 2018. Universitas Hasanuddin Makassar.

Notoatmodjo, S. (2010). Ilmu Perilaku Kesehatan. Jakarta: Rineka Cipta.
Notoatmodjo, S. (2011). Kesehatan Masyarakat Ilmu dan Seni. Jakarta: Rineka Cipta.

Nursalam. (2008). Konsep dan Penerapan Metodologi Penelitian. Surabaya: Salemba Medika.

Pangihutan, S. R. S. (2019). Factors Related to Behavior of Using Personal Protective Equipment on Filling Lithos Workers. The Indonesian Journal of Occupational Safety and Health, 8(3), 302-309.

Sanjaya, V. D. (2018). Hubungan Sikap dan Ketersediaan Alat Pelindung Diri (APD) Dengan Kepatuhan Bidan Menggunakan APD dalam Pertolongan Persalinan Normal di Puskesmas Rawat Inap Kabupaten Sleman.

Supiana, N. (2013). Hubungan Predisposing, Enabling dan Reinforcing Faktor dengan Penggunaan APD pada Bidan dalam Pelayanan Kebidanan di Rumah Sakit KIA Sadewa Yogyakarta Tahun 2013.

World Health Organization. Coronavirus (COVID-19) Retrieved 30 April 2020, from https://covid19.who.int/

World Health Organization. Coronavirus Disease (COVID-19) Pandemic, from

https://www.who.int/emergencies/d iseases/novel-coronavirus-2019

Zaki, M., Ferusgel, A., \& Siregar, D. M. S. (2018). Faktor - Faktor Yang Memengaruhi Penggunaan Alat Pelindung Diri (Apd) Tenaga Kesehatan Perawat Di Rsud Dr. Rm. Pratomo Bagansiapiapi Kabupaten Rokan Hilir. Excellent Midwifery Journal. 